\title{
The Implementation of Supply Chain Management at "Sale Pisang" Businesses to Face MEA
}

\author{
Author \\ Amalina Maryam Zakiyyah, Ulya Anisatur Rosyidah \\ Correspondence \\ Universitas Muhammadiyah Jember \\ amalinamaryam@unmuhjember.ac.id, ulyaanisatur@unmuhjember.ac.id
}

\begin{abstract}
Home Industry "Sale pisang” Banyuwangi UD. Della Sale is one of the many UMKM producers of Banyuwangi souvenirs. The home industry faces several problems, namely (1) the shelf life of the fried "sale pisang" product is relatively short because of draining oil process is not maximal. (2) Product marketing is still limited. Maharani Community seeks to increase the income of its assisted people by cooperating with UD. Della Sale and acts as a distributor of "sale pisang" products. However, members of the Maharani Community do not have the knowledge and skills of financial management and marketing, so it makes difficult to develop. Therefore, this activity aims to improve the quality of production and increase the demand for "sale pisang" products through Supply Chan Management to face competition in the era of the ASEAN Economic Community (MEA). In this PKM activity, there are 3 (three) activities with the following objectives: The first activity aims to provide appropriate technology in the form of Spinner machines for draining oil to prevent changes in taste and quality of "sale pisang". And the packaging machine is a vacuum sealer to make the product more durable and long lasting. The second activity is designing e-commerce websites and providing knowledge and assistance for product marketing. The third activity aims to provide knowledge about financial management by providing financial management materials with UMKM accounting standards.
\end{abstract}

Keywords: spinner; vacuum sealer; SCM; barlin banana; sale pisang

\section{Introduction}

"Banana sale" is processed food from banana which is known to have a distinctive taste and aroma (Wikipedia). The processing method is banana sliced thinly, but not as thin as or thicker than banana slices which will be processed into banana chips, then dried by drying or smoked. The drying and fumigation process is carried out aiming to reduce the moisture content of bananas so that the resulting "banana sale" is more durable and long lasting. Banana sale can be directly consumed and known as Wet Banana Sale, or processed again by frying with flour and known as Fried Banana Sale.

The quality of banana sale products is largely determined by color, taste, odor, suppleness, and storage resistance (Salafi, 2014). All of these indicators are largely influenced by the processing, packaging and storage of banana sale products. So far, sale made is often of poor quality, one of them is the Fried Banana Sale product, there is still a lot of oil left over from the frying process which reduces the durability of product storage. This
Received: 07 Januari 2019. Accepted: 23 Januari 2019

condition is an obstacle for Sale Pisang home producers in an effort to improve competitiveness in the current ASEAN Economic Community (MEA).

The raw material for banana sale in Banyuwangi is Barlin banana, because Barlin banana is banana found in many parts of East Java, especially Banyuwangi. With a tiny shape, Barlin banana has very sweet flavor. However, the selling price of Barlin banana, which is a type of dessert banana, is very cheap if sold just like that without being processed again because it can only be stored for about 5 days (Sondak, Minantyo, \& Winarno, 2018). So, to increase its value, Barlin banana is reprocessed into a banana sale.

In addition to product quality constraints, the banana sale is still not optimally marketed. Bookings that have been available all this time only rely on word of mouth promotions made by consumers who have already ordered a sale. There is no good marketing makes the special production of Banyuwangi has not experienced an increase in the number of requests. 
This has encouraged a Maharani community in Jember to act as a distributor that holds the sale of craftsmen from Banyuwangi to be marketed widely in the form of Supply Chain Management (SCM).

Supply chain is a business processes network and interrelations between businesses needed to build, sell, and deliver a product to the end customer (Suyanto, 191).

The SCM channel places the sale craftsmen as suppliers and the Jember Community as distributors who will ensure the products are delivered to the customers.

Where it is expected that with the cooperation of sale craftsmen as suppliers and communities in Jember as producers can increase the competitiveness of craftsmen sale and increase profits from the addition of additional orders obtained.

Maharani community was initiated to activate the role of a young mothers' group in the Keramat Jember housing area who came from several different backgrounds, so that they could be more beneficial to the surrounding community.

The initial activity of the Maharani community was to carry out a movement to care for the poor by collecting donations from members and donors and then giving them in the form of basic necessities. This activity, which they named Maharani PEDULI, received a good response and increased the number of donors in the following month. However, at the next level community members want to have their own income to finance their philanthropic activities. For this purpose, they took the initiative to become a distributor for banana sale of Banyuwangi. However, there are a number of constraints; namely, marketing problems that have not applied the latest technology, especially the product shelf life that cannot long lasting, so community members do not dare to distribute products in large quantities.

From the situation analysis of the two partners, this activity aims to increase the quantity and quality of production of banana sale so it can increase the income of local banana sale producers. With a specific target that is namely the application of information technology in an effort to sell "banana sale".

\section{Implementation Method}

Based on the solutions and output targets proposed in the Community Service Program (PKM), the stages in implementing solutions in the fields of production, marketing and management are described.

Table 1. Stages of Field PKM Activities in Production:

\begin{tabular}{ll}
\hline \multicolumn{1}{c}{ Solution } & \multicolumn{1}{c}{ Output } \\
\hline Provision and Mentoring & Availability of spinner machines \\
Application of Appropriate & and operating manuals, as well as \\
Technology & vacuum sealer machines \\
& Knowledge and skills for using \\
& spinner and vacuum sealer \\
& machines \\
\hline
\end{tabular}

In the provision and mentoring program for the application of Appropriate Technology, the Proponent Team acts as (1) Provider of spinner oil draining machines and vacuum sealer packaging machines, (2) Proper testers of spinner and vacuum sealer machines and installations, and (3) Production process assistance using machines spinner and packaging process using a vacuum sealer. Both partners act as providers of information regarding the production process for the machines in accordance with the required specifications. Then the two partners acted as trainees and assisted the use of spinner and vacuum sealer machines.

Table 2. Stages of PKM Program Activities in Marketing

\begin{tabular}{ll}
\hline \multicolumn{1}{c}{ Solution } & \multicolumn{1}{c}{ Output } \\
\hline E-Commerce Website & E-commerce website is available \\
Training and Marketing & Knowledge and operating \\
Assistance & technical skills of e-commerce \\
& website \\
& Small business marketing unit \\
\hline
\end{tabular}

In marketing training and mentoring programs through e-commerce websites, the Proposal Team acts as (1) Software designer namely e-commerce website, (2) Verification and validation of services or the main marketing features and supporting features, (3) Training and companion training activities and web operation practices during PKM program implementation, and (4) Marketing strategy development consultants.

This web-based application has a commercial business domain name with the extension $*$.com (www.maharanistore.com) and paid hosting.

Table 3. Stages of PKM Activities in Management 


\begin{tabular}{ll}
\hline \multicolumn{1}{c}{ Solution } & \multicolumn{1}{c}{ Output } \\
\hline Training and Assistance & Knowledge and financial management \\
for Small Business & skills of small businesses \\
Financial Management & $\begin{array}{l}\text { Bookkeeping of small business } \\
\text { financial administration }\end{array}$ \\
\hline
\end{tabular}

In training programs and financial management assistance for small businesses, the Proposal Team acts as (1) Presenters in training on small business financial management, (2) Mentors in mentoring the application of financial management to ensure the business runs well, and (3) Standard makers recording of incoming and outgoing and accompanying money transactions in making financial statements. MAHARANI community partners act as participants in the training and mentoring of small business financial management, who apply the material then that has been received in the training.

\section{Results and Discussion}

The implementation of PKM activities began with an initial survey and initial coordination with partners, both partners 1 namely UD Della Sale in Srono Banyuwangi and partner 2 namely Maharani Community in Jember.

Then it continued with the procurement of appropriate technology namely e-commerce web, spinner machines, and vacuum sealers. After procuring the tool, continue with the handover of the tool to the partner. Along with the handover, training and dissemination of the use of appropriate technology were also carried out. With the following explanation:

\subsection{Survey and Initial Coordination}

The executive team conducted an initial survey and coordination with partners, either partner1 or 2. The purpose of this initial survey and coordination was to ascertain the findings of the actual problems and conditions of the partners, so that the solution we offered for the partners' problems was right on target. In addition, this activity also aims to introduce ourselves and this community partnership program to partners. The results obtained from this activity are:

a. Agreement between the executive team and partners regarding the schedule and date for carrying out further activities.

b. Examples of products that have been produced by partners.

The survey on partner 1, namely UD Della Sale in Srono, Banyuwangi was conducted on May 19,
2018. At this survey, we learned that the name of the partner we submitted for this program had changed its name. Originally named UD Wiwin Handayani it changed to UD Della Sale. The survey activity was carried out by the executive team which was also accompanied by one of the administrators of the Maharani Community as partner 2, namely Mrs. Minuk. Furthermore, the survey and coordination with partner 2 of Maharani Community in Jember will be held on May 26, 2018.

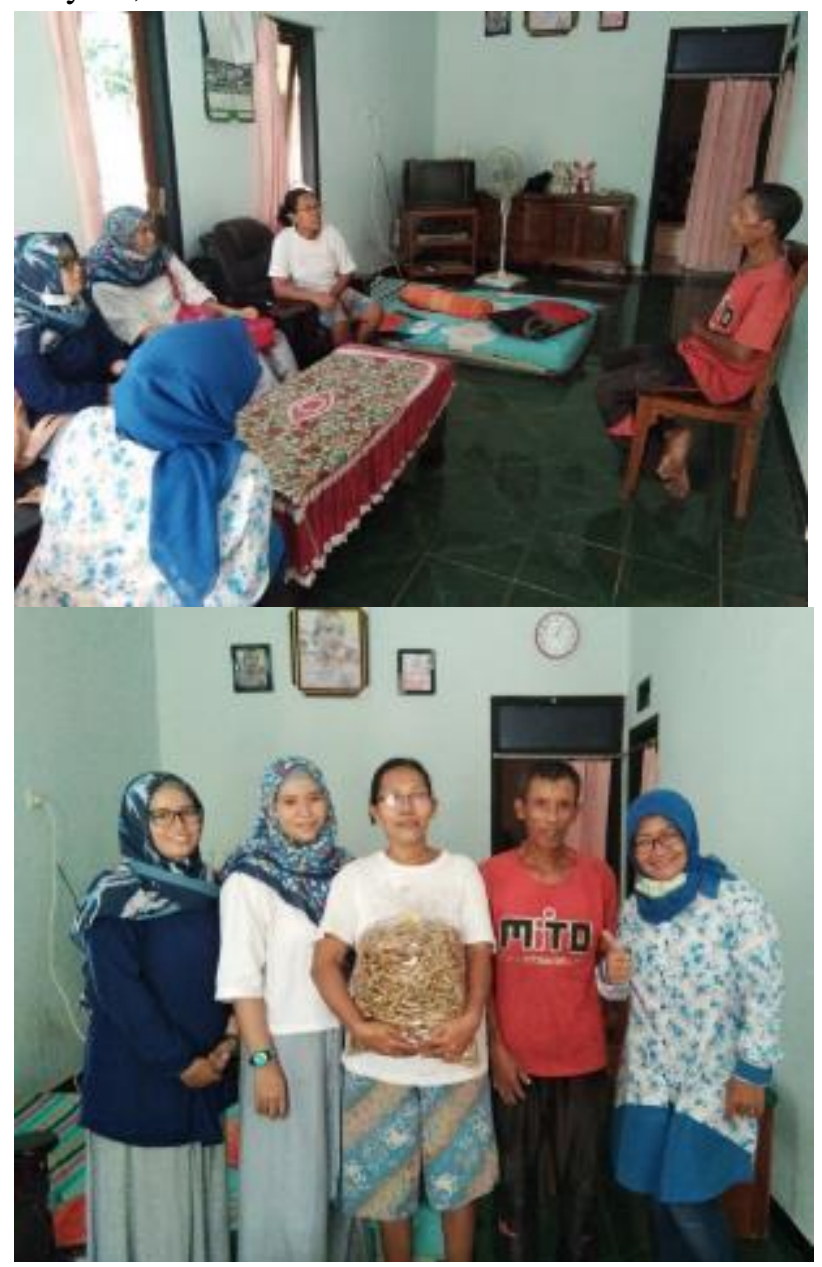

Figure 1 Coordination of the Executive Team and Partners

\subsection{Procurement of Appropriate Technology}

After survey and agreement with partners have been found, the next activity carried out is the procurement of appropriate technology that is in accordance with the partners' problems. For partner 1 as a craftsman or manufacturer of banana sale, we have a spinner machine to improve the quality of production. As for partner 2 as a distribution network of banana sales, we hold e-commerce webs and vacuum sealer machines. In addition, we also add digital scales which are expected to also 
be able to improve quality with quality control in terms of product weight.

The process of creating our web is entrusted to credible web developers for several reasons, especially maintaining the quality of the web to remain excellent and easy to use for the Maharani Community mothers. The length of the process of making this web is approximately 3 weeks until it is ready to operate. Maharanistore.com and hosting domain purchases are made on June 11, 2018. After the manufacturing process, the web designer coordinates or short training to the technician who is the admin of the web.

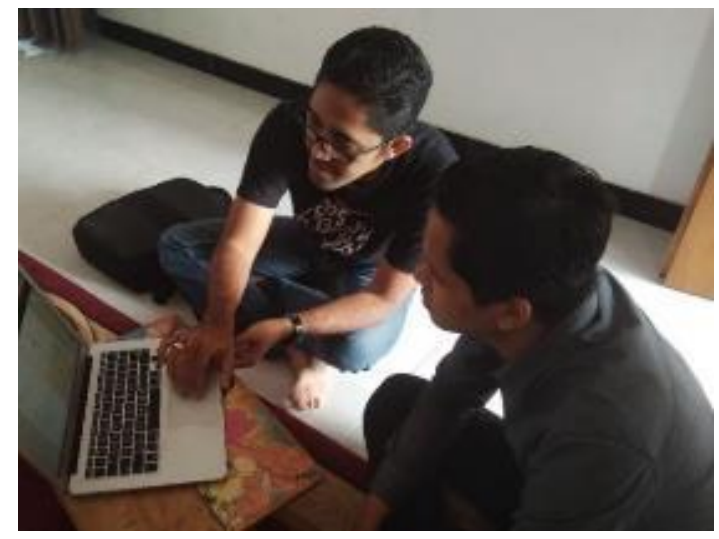

Figure 2 Web Creation

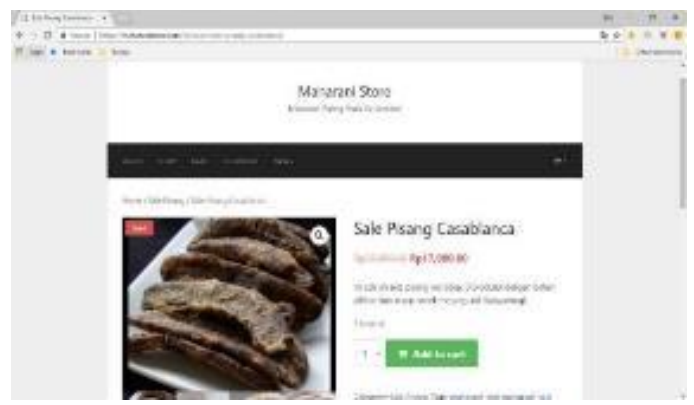

Figure 3 Web Views

The procurement of other appropriate technologies is a spinner machine or oil drainer. We procure this machine with the purchase of a machine shop for businesses in Jember on July 16 , 2018. This spinner machine has the following specifications:

Table 4. Spinner Machine Specifications

\begin{tabular}{ll}
\hline Machine & Oil Drainer \\
Voltage & $220-240$ Volt \\
Frequency & $50 / 60 \mathrm{~Hz}$ \\
Electric Power & $200 \mathrm{Watt} / 1 / 4 \mathrm{HP}$ \\
Capacity & $5 \mathrm{Kg} /$ Process \\
Cylinder Material & 304 Stainless Steel \\
Basket Material & Stainless Steel Vaporization \\
Tube Material & 304 Stainless Steel \\
Dimensions & $600 \mathrm{~mm} \times 400 \mathrm{~mm} \times 520 \mathrm{~mm}$ \\
\hline
\end{tabular}

Table 5. Vacuum Sealer Specifications

\begin{tabular}{ll}
\hline Voltage & $220 \mathrm{~V}-50 \mathrm{~Hz} / 110 \mathrm{~W}$ \\
Work Model & Full Automatic / Manual \\
Vacuum Level & $-60 \mathrm{kpa}$ Max \\
Seal Width & $\leq 30 \mathrm{~cm}$ \\
Seal Thickness & $2 \mathrm{~mm}$ \\
Size & $35.6 \times 17.9 \times 7.6 \mathrm{~cm}$ \\
Net Weight & $1.2 \mathrm{~kg}$ \\
\hline
\end{tabular}

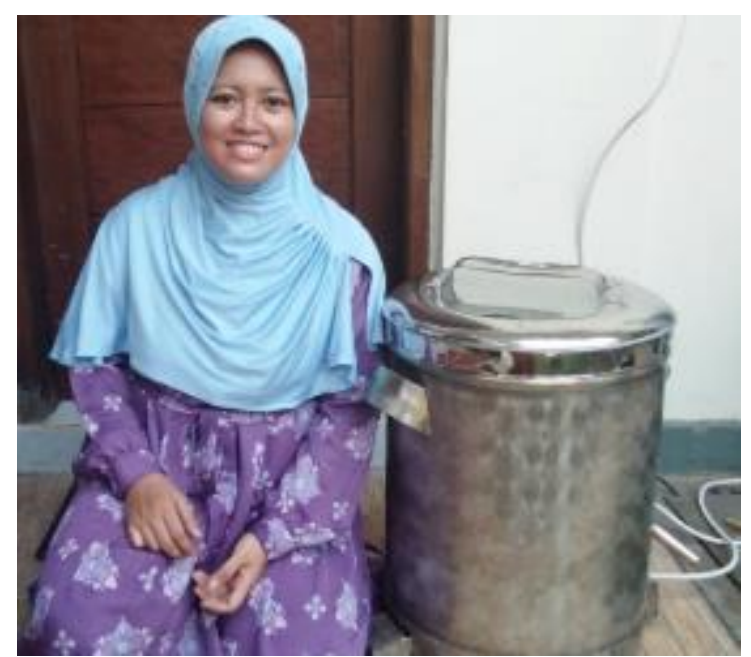

Figure 4 Spinner Machine

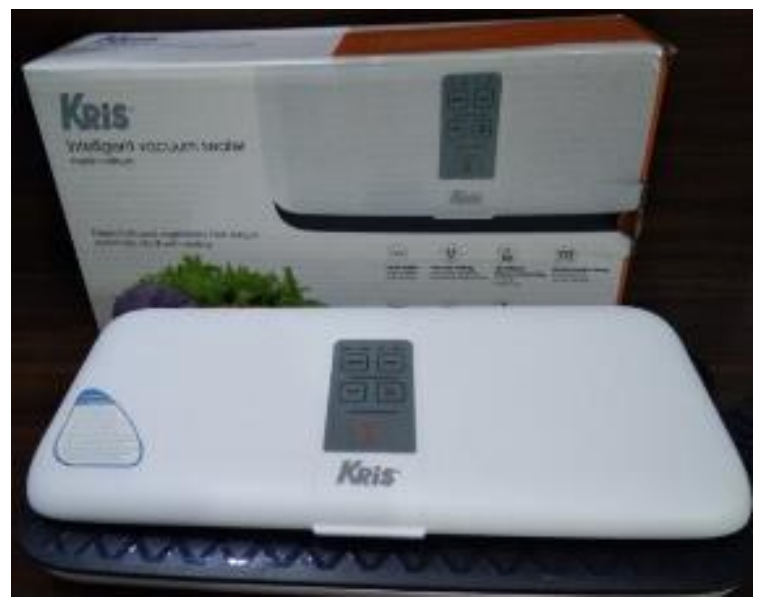

Figure 5 Vacuum Sealer

Purchases of vacuum sealers and digital scales were carried out on July 26, 2018 in two different places which we conducted a survey in advance about the place to purchase the two devices.

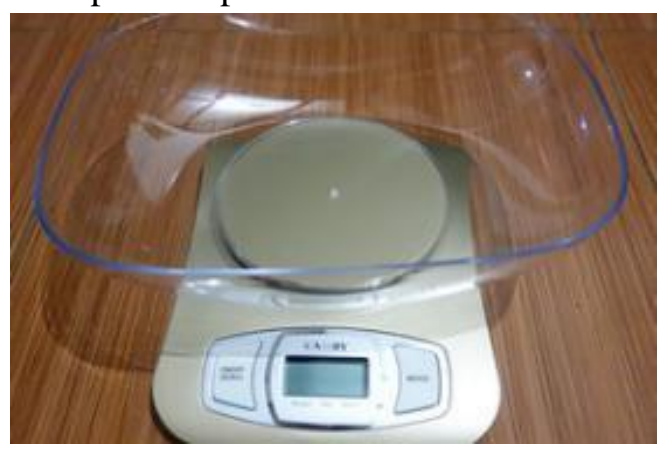


Figure 6 Digital Scales

Table 6. The Digital Scales specifications are as follows:

Accuracy rate is very high accuracy up to 1 gram

Simple and Elegant Design

Auto On Off

Material: ABS plastic

Max $5 \mathrm{~kg} / 11 \mathrm{lb}$

LCD size $46 \times 17 \mathrm{~mm}$

Camry Scales EK 3650 / EK 3651

\subsection{Handover and Training}

Handover of equipment is carried out in stages according to the stages of procurement of appropriate technology. With the schedule as follows:

Table 7 Handover Schedule

\begin{tabular}{cl}
\hline \multicolumn{1}{c}{ Date } & \multicolumn{1}{c}{ Activity } \\
\hline July 21, 2018 & $\begin{array}{l}\text { Handover of spinner machines at Mitra 1 UD } \\
\text { Della Sale Srono, Banyuwangi }\end{array}$ \\
July 28, 2018 & $\begin{array}{l}\text { Handover of vacuum sealers and digital scales } \\
\text { at Mitra 2 Maharani Community, Sumbersari }\end{array}$ \\
& $\begin{array}{l}\text { Jember. } \\
\text { July 30, 2018 }\end{array}$ \\
& $\begin{array}{l}\text { Handover of e-commerce web at Mitra 2 } \\
\text { Maharani Community, Sumbersari Jember. }\end{array}$ \\
\hline
\end{tabular}

The executive team brought a spinner machine from campus Muhammadiyah Jember University with a rental car. Then we drove to Banyuwangi precisely in Srono sub-district, Rejoagung village to deliver the machine to UD Della Sale.

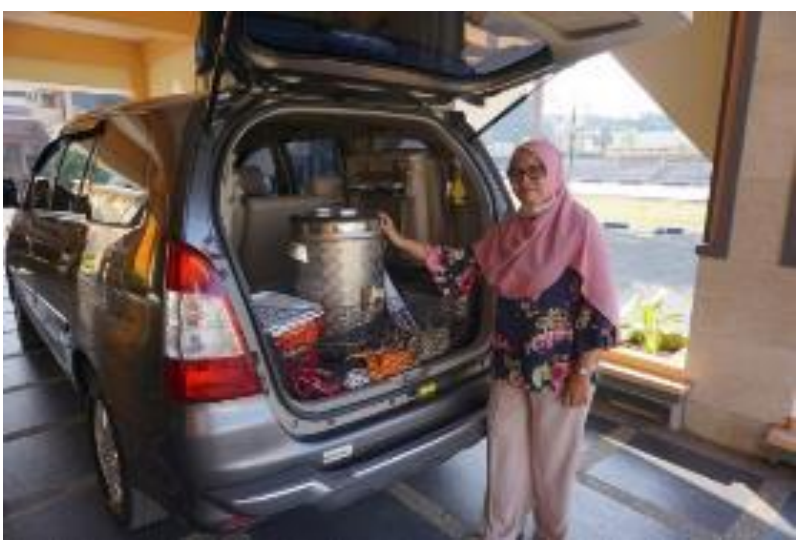

Figure 7 Preparation for Handover

Upon our arrival at UD Della Sale, we were greeted enthusiastically by the participants that we collected. Participants were local residents who were also workers at UD Della Sale when there were a lot of raw materials and had to make large quantities of production.

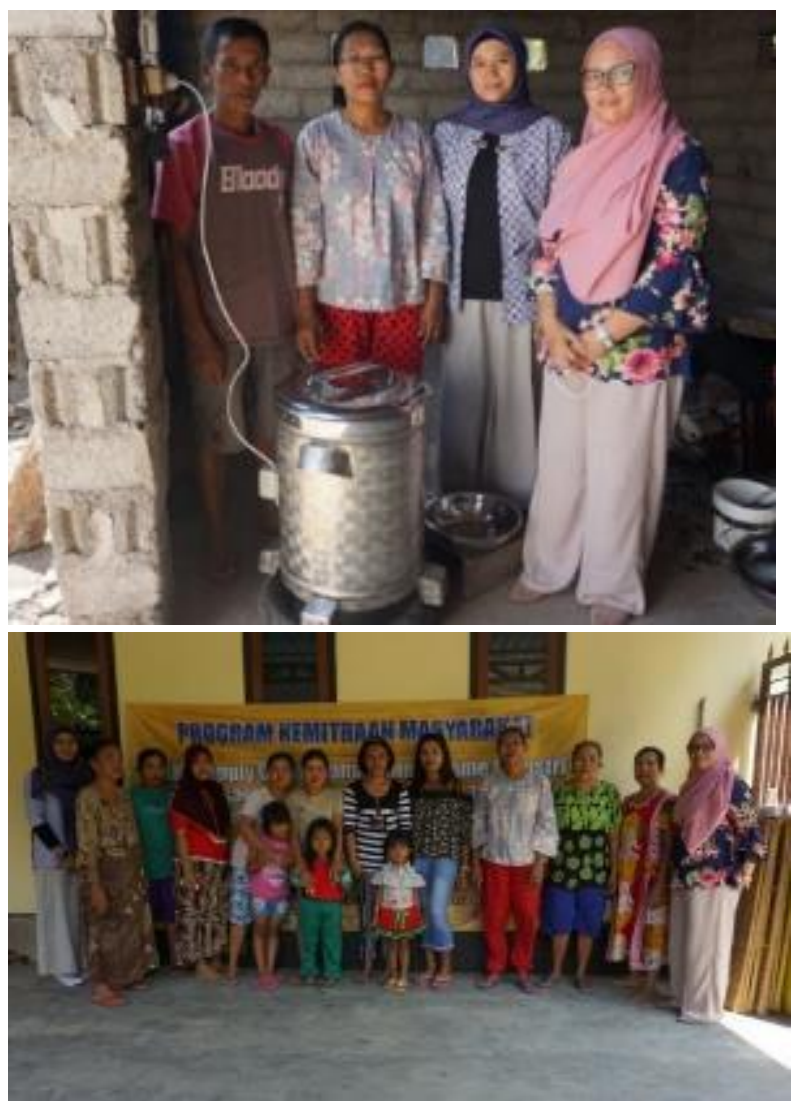

Figure 8 Handover to Della Sale

On July 28 , the executive team handed over a vacuum sealer machine and gave training to operate it at the Maharani Community.

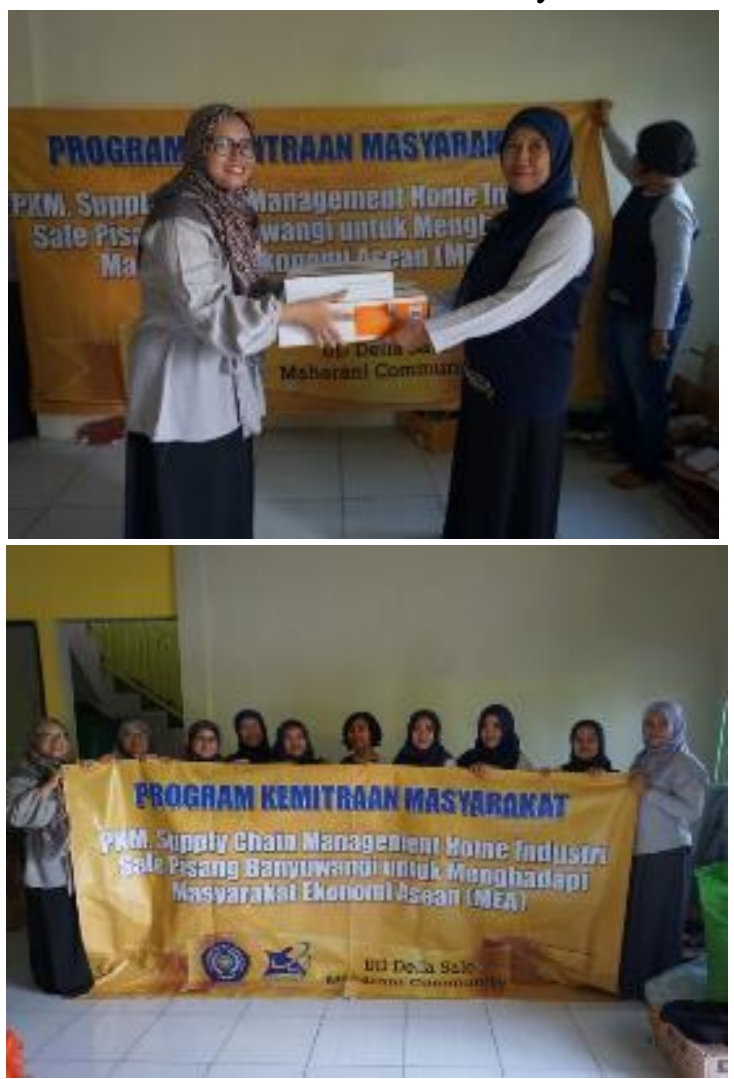

Figure 9 Handover to Maharani Community 

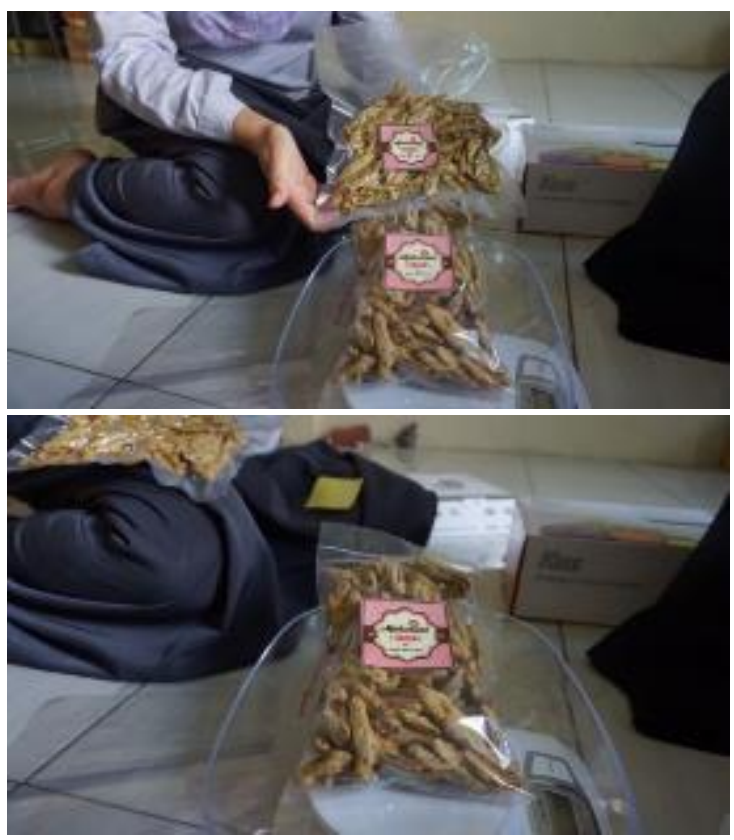

Figure 10 Packaging Test

On July 30 towards the end of reporting, we made a handover of the website to the Maharani Community. Then there is the training on how the website works which is able to reach potential customers from all over Indonesia.

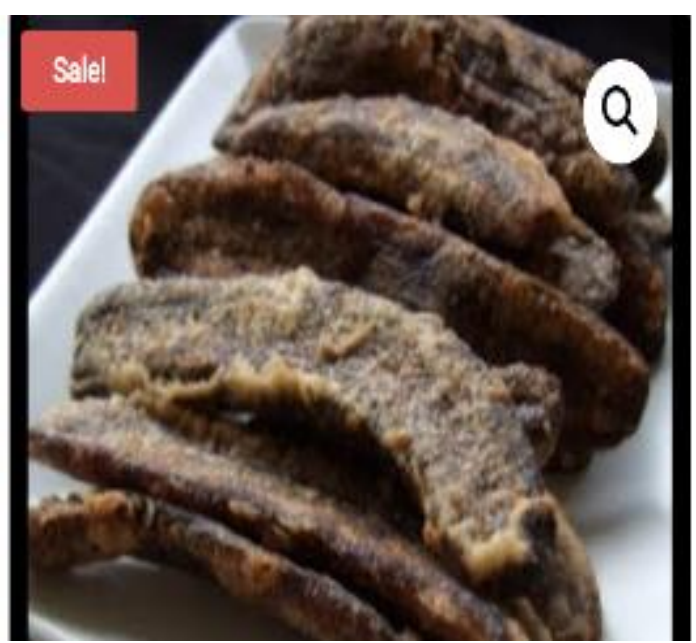

Figure 11 Sale Pisang Casablanca

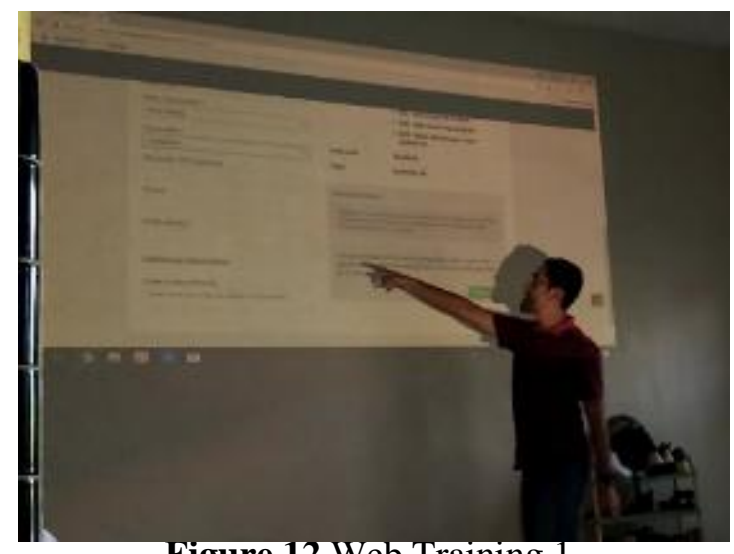

Figure 12 Web Training 1

\section{Conclusion}

The activities of the Community Partnership Program (PKM) on Chain Management Inventory in Banana Sale home-based businesses in Banyuwangi are as follows:

1. The executive team has procured appropriate technology in this case a spinner, vacuum sealer, digital scale and e-commerce website maharanistore.com.

2. Partners from this PKM program have received the appropriate technology mentioned above and also received training in how to operate it.

3. The use of websites in home-based and small businesses is very necessary to improve business competitiveness in facing MEA.

\section{Reference}

https://id.m.wikipedia.org/wiki/Sale_Pisang https://id.wikipedia.org/wiki/Sale_Pisang https://id.wikipedia.org/wiki/Kabupaten_Banyuwa ngi

http://banyuwangikab.go.id/

Salafi, M. F. (2014, Januari 2). Harga Sale Pisang Banyuwangi. Retrieved from oleholehkhasbanyuwangiku.wordpress.com: https://oleholehkhasbanyuwangiku.wordpress .com/2014/01/02/harga-sale-pisangbanyuwangi/

Sondak, M. R., Minantyo, H., \& Winarno, P. S. (2018). INNOVATION TO PISANG BARLIN (MUSA ACUMINATA AA) AS THE SUBSTITUTE FLOUR. Jurnal Bahan Alam Terbarukan, 89-95.

Suyanto, M. 2007. Strategic Management Global Most Admired Companies: Perusahaan yang Paling Dikagumi Dunia. Yogyakarta: C.V Andi Offset. 